\title{
Regional Branching Reconsidered: Emergence of the Fuel Cell Industry in European Regions
}

Tanner, Anne Nygaard

Published in:

Economic Geography

Link to article, DOI:

10.1111/ecge.12055

Publication date:

2014

Document Version

Peer reviewed version

Link back to DTU Orbit

Citation (APA):

Tanner, A. N. (2014). Regional Branching Reconsidered: Emergence of the Fuel Cell Industry in European Regions. Economic Geography, 90(4), 403-427. https://doi.org/10.1111/ecge.12055

\section{General rights}

Copyright and moral rights for the publications made accessible in the public portal are retained by the authors and/or other copyright owners and it is a condition of accessing publications that users recognise and abide by the legal requirements associated with these rights.

- Users may download and print one copy of any publication from the public portal for the purpose of private study or research.

- You may not further distribute the material or use it for any profit-making activity or commercial gain

- You may freely distribute the URL identifying the publication in the public portal

If you believe that this document breaches copyright please contact us providing details, and we will remove access to the work immediately and investigate your claim. 
Running head: Regional Branching Reconsidered

\section{Regional Branching Reconsidered: Emergence of the Fuel}

\section{Cell Industry in European Regions}

This is an Accepted Manuscript of an article published by Taylor \& Francis in Economic Geography on 24 April 2014, available online: http://www.tandfonline.com/ DOI: https://doi.org/10.1111/ecge.12055

\section{Anne Nygaard Tanner}

Technical University of Denmark, Department of Management Engineering Produktionstorvet 426, Room 033B

DK-2800 Kgs. Lyngby

Denmark anny@dtu.dk

Key words:

regional branching

emerging industry

diversification

technological relatedness

fuel cells 


\section{Abstract}

The literature on economic geography suffers from a lack of attention to the emergence of new industries. Recent literature on "regional branching” proposes that new industries emerge in regions where preexisting economic activities are technologically related to the emerging industry. This article provides a more-grounded basis for the emerging literature on regional branching by confronting the regional branching thesis with the realities of an emerging industry, namely, the fuel cell industry. The analysis is based on patent data and qualitative interviews conducted in a selection of European NUTS2 (nomenclature of territorial units for statistics) regions. The findings can be summarized as follows. First, the analysis reveals that in the case of the emerging fuel cell industry, regional diversification is dominated by firm diversification, which complements previous studies’ findings that entrepreneurial spin-offs dominate regional diversification. Second, the study corroborates the assumption that the process of regional branching relies on knowledge generated by nonindustrial actors such as universities and research institutes. Third, the findings suggest that care should be taken in ascribing the underlying logic of regional branching to the principle of technological relatedness alone. The article shows how some regional diversification processes occur in regions where preexisting economic activities are not technologically related to the emerging industry, for instance, when user industries apply new technologies to their product portfolio. The importance of further investigating and disentangling different dimensions of relatedness and their impact on regional branching is stressed. 


\section{Introduction}

This article examines the emergence of a new industry in its geographic context. Emerging industries attract substantial academic and policy interest since new industries are associated with innovation and entrepreneurial activity that can provide a platform for future economic growth (Feldman and Lendel 2010). In the field of economic geography, the spatial process of industry emergence has likewise received renewed attention.

An emerging literature with roots in evolutionary economic geography (Grabher 2009; Boschma and Frenken 2006; Boschma and Martin 2007) argues that new industries tend to emerge in locations where preexisting industries are technologically related to the new industries (Boschma and Frenken 2011b). Boschma and Frenken have metaphorically labeled this process "regional branching," a term that reflects how new regional industrial paths grow out of technologically related preexisting industries. ${ }^{1}$ Regional branching has been empirically confirmed in the long-term economic evolution of regions in Sweden (Neffke, Henning, and Boschma 2011a), the emergence of new industries at the regional level in Spain (Boschma, Minondo, and Navarro 2013), and in the case of the emerging fuel cell industry across regions in Europe (Tanner 2011).

The concept of regional branching is a much-needed contribution to the field of economic geography and is particularly useful for understanding how new economic growth paths may be linked to preexisting industry structures in a region. First, the temporal scope of the regional branching thesis allows us to focus on how new industries come into being, a focus that much previous economic geography literature has lacked. Second, the regional branching thesis focuses on knowledge spillover

\footnotetext{
${ }^{1}$ The regional level refers to regions at the subnational level.
} 
effects based on diversity and related variety (Jacobs 1969), which have been shown to enhance employment growth (Frenken, Van Oort, and Verburg 2007), rather than on specialization effects (MAR [Marshall-Arrow-Romer] externalities). For policy makers, the concept of regional branching thus complements the vast literature on clusters, industrial agglomeration, etc., because it enables more strategic regional innovation policy. Whereas much cluster-based policy has focused excessively on supporting and creating interfirm networks, the regional branching approach also emphasizes the advantages of supporting networks that are in cognitive proximity to the preexisting industrial structure of a region. Consequently, the regional branching thesis may suggest some novel recommendations for policy makers.

However, the emerging literature on regional branching has numerous shortcomings, which are the focus of this article. First, the literature lacks a thorough understanding of the mechanisms that drive regional branching (Neffke et al. 2011a). It has been argued that regional branching operates through knowledge-transfer mechanisms such as firm diversification, entrepreneurial spin-offs, labor mobility, and social networking. These mechanisms function as knowledge channels from a preexisting industry to the emerging industry and have a strong local bias (Boschma et al. 2013; Boschma and Frenken 2011a). Previous studies show that entrepreneurial spin- offs have been the driving force in some emerging industries (Boschma and Wenting 2007; Klepper 2010). However, more study is needed to determine which mechanisms drive the emergence of industries in other cases.

Second, related to the above, it is also important to examine the fundamental claim regarding what drives the mechanisms of regional branching. The underlying logic of regional branching is technological relatedness between preexisting economic activities and the new activity. However, how technological relatedness is defined is often unclear, and it often appears that any type of connection between two industries is 
ascribed to technological relatedness. Therefore, this article aims to take a first step toward clarifying whether technological relatedness is always the underlying logic of regional branching.

Finally, the literature on regional branching appears predisposed to consider industrial factors in explaining regional diversification processes but may focus inadequately on the role of universities and research institutes.

This article provides a more-grounded basis for the regional branching thesis by shedding light on the above-mentioned shortcomings. To do so, this article confronts the regional branching thesis with the realities of an emerging industry, namely, the fuel cell industry. By studying the emergence of a new industry in "real time," an opportunity to refine the concept of regional branching is offered. Hence, this article aims to complement recent quantitative contributions (Tanner 2011; Neffke et al. 2011a; Boschma et al. 2013) with qualitative insight into the underlying processes of regional branching by comparing the evolution of the emerging fuel cell industry in several regions of Europe.

The article introduces the context of fuel cell technology development and the emerging fuel cell industry. Then it outlines the theoretical understanding of industry emergence as a spatial process, before it takes a critical look on the regional branching thesis. The methodological approach that is employed is described, followed by an analysis, which is twofold. First, the analysis maps the NUTS2 (nomenclature of territorial units for statistics) regions in Europe with the highest shares of fuel cell patent applications. Second, the analysis examines the different types of regional branching mechanisms that characterize these regions' branching processes. Findings are then discussed, followed by a summary of the main conclusions. 


\section{Emerging Fuel Cell Industry}

A fuel cell is an electrochemical device that generates electricity from a chemical reaction between a fuel, usually hydrogen, and oxygen. The scientific principle behind fuel cells has been known since William Grove discovered it in 1839 (Basu 2007). Fuel cells have also been used in National Aeronautics and Space Administration (NASA) spacecraft programs since the 1960s and 1970s. However, the large-scale potential of fuel cells was recognized due to progress in various related scientific fields such as material science, chemistry, and nanotechnology. These and other knowledge fields play key roles in the development of fuel cell technology and form the emerging technology's knowledge base.

Technological changes in the fields of fuel cells and hydrogen are highly systemic and complex. Thus, technological improvements (or impediments) in one component improve (or inhibit) the performance and cost of the entire system. The interdependence between components is similarly reflected in the highly complex fuel cell knowledge base (Tanner 2011; Dibiaggio and Nasiriyar 2009), which requires a broad scope of in-depth and interdependent competences (Hellman and van den Hoed 2007). The systemic and immature nature of the technology implies that innovation requires extensive cooperation and coordination along the value chain in addition to supportive institutional structures (Hellman and van den Hoed 2007; Musiolik and Markard 2011).

Fuel cell technology and the emerging industry that has evolved around it belong to a wider platform of innovations referred to as "green innovations” (Cooke 2010). The green potential of hydrogen fuel cells makes it a promising alternative to incumbent energy technologies; accordingly, it has attracted the interest of various types of enterprises and significant policy and research interest as well. The emerging fuel cell 
industry is currently characterized by a mix of young, dedicated fuel cell firms and large incumbent multinational enterprises (MNEs) (Hellman and van den Hoed 2007; Pilkington et al. 2009; Brown, Hendry, and Harborne 2007). In addition, a wide range of supporting actors, such as universities, public-private partnerships, and formal networks at the regional, national, and international levels, is involved in fuel cell and hydrogenrelated activities (Madsen and Andersen 2010; Musiolik and Markard 2011; Bourgeois and Mima 2003; Mans et al. 2008). Their interest is based on the potential of fuel cells to solve the challenges that dominate the energy agenda such as the need for self-sufficient energy supplies and local and global environmental concerns.

The widespread interest in fuel cell technology has culminated in the concept of a "hydrogen economy" as a substitute for the fossil fuel-based economy, with hydrogen rather than oil and coal serving as the major energy carrier (Rifkin 2004). Realization of a hydrogen economy might seem far off, especially given the reduced expectations that followed the hydrogen hype of the early 2000s. However, none of these challenges appear to have weakened interest and effort invested in developing the technology (Ruef and Markard 2010).

Fuel cell technology can replace batteries, internal combustion engines, and oil boilers; hence, it is applicable in a wide range of energy-related sectors, including portable equipment, such as mobile phones and laptops; stationary power units, including back-up power units and combined heat and power systems; and the transport sector, as a new means of propulsion or as auxiliary power units. Although fuel cell technology outperforms incumbent energy technologies on a number of nontraditional performance measures - for example, in that it involves no noise, no exhaust, and no moving partsthe technology requires further enhancements to improve costs, traditional performance measures, and overall reliability. Hence, application of fuel cell systems to products continues to face various challenges. First, fuel cell technology 
faces severe lock-in of incumbent energy technologies, such that the transition can be compared to other large paradigm shifts, for example, the steam engine and electric power. These new paradigms may require long gestation periods because of inertia in the incumbent systems (Perez 1983; in Freeman 1996), which may explain the difficulties this green innovation faces in reaching markets. Second, fuel cell technology competes with other emerging technologies that could replace the incumbent energy technologies.

Aside from several qualitative case studies of hydrogen and fuel cell cluster initiatives (Mans et al. 2008; Holbrook, Arthurs, and Cassidy 2010; Amesse, Avadikyan, and Legault, the emergence of the fuel cell industry and its geographic context have not been analyzed systematically. This article takes up this challenge and scrutinizes in greater detail the regional knowledge dynamics that characterize the process of regional branching in the emerging fuel cell industry.

\section{Emergence of Industries and Economic Geography}

Most of the economic geography literature focuses on localized learning and agglomeration externalities framed by concepts such as industrial districts, clusters, innovative milieu, and regional innovation systems (Asheim, Smith, and Oughton 2011). Core questions about industry emergence, such as "How do industries come into being?” and “To what extent is industry emergence embedded in geographic territories?" have received comparatively little attention. Only recently, with the evolutionary turn in economic geography (Boschma and Martin 2007; Grabher 2009; Boschma and Frenken 2006), have scholars begun to focus on the origin and early evolution of industries (Storper and Walker 1989; Boschma and Lambooy 1999; Tanner 2011, 2012; Boschma, Minondo, and Navarro 2013) and on the emergence of clusters 
(Braunerhjelm and Feldman 2006; Martin and Sunley 2011; Menzel, Henn, and Fornahl 2010).

As Abernathy and Utterback (1978) note, emerging industries are difficult to study because they are challenging to identify and track until after their products appear in the market. This encumbrance is associated with a lack of adequate data regarding industrial classification schemes (e.g., Standard Industrial Classification (SIC), Nomenclature of Economic Activities (NACE)), which are typically based on existing industry groupings and are consequently problematic in studies of emerging industries.

Forbes and Kirsch (2010) observe that scholars tend to stop asking questions about phenomena, such as the emergence of industries, that are difficult to study empirically. This aversion could also explain why industry emergence has received so little attention in the field of economic geography; however, the reason can also be found in the temporal scope of most industry studies in the field of economic geography.

Several different emerging industries have received attention in economic geography (see, e.g., Feldman and Lendel 2010; Feldman 2003; Dahl, Østergaard, and Dalum 2010; Zucker, Darby, and Brewer 1998; Zucker et al. 2007), but they have primarily been studied through the lens of clusters (Braunerhjelm and Feldman 2006; Menzel et al. 2010; Menzel and Fornahl 2010) or the "industry life cycle” (see, e.g., Audretsch and Feldman 1996; Neffke et al. 2011b). Owing to the inherent temporal focus of both approaches to industry development after market introduction, cluster- studies and industry life cycle-studies face difficulties in grasping the essentials of how new industries come into being and, thus, how this process is embedded in specific regional contexts.

The regional branching thesis pays closer attention to this temporal gap by focusing on how new and old activities are connected through knowledge externalities. 
The regional branching thesis has roots in evolutionary economics (Nelson and Winter 1982; Dosi 1988) and connects concepts, such as related variety (Jacobs 1969) and optimal cognitive proximity (Nooteboom 1999), with Penrose's resource-based view of the firm (Penrose 1959).

\section{REGIONAL BRANCHING RECONSIDERED}

This section takes a critical view in considering three issues: (1) the concept of technological relatedness and its key role in the regional branching thesis, (2) the fact that diversification also occurs on the basis of technologically unrelated competences, and (3) the role of other knowledge-producing actors such as universities and research institutes in regional branching.

\section{Technological Relatedness}

The main claim of the regional branching thesis is that new industries are more likely to develop in regions where preexisting industries are technologically related to the emerging industry (Boschma and Frenken 2011a, 2011b; Neffke et al. 2011a). Regions are therefore said to diversify across technologically related industries. Technological relatedness between two or more industries consequently becomes a key concept in the theorization of regional branching.

Breschi, Lissoni, and Malerba (2003) describe technological relatedness as existing between two industries when both industries share a common or complementary knowledge base and rely on common scientific and/or engineering principles. However, in most studies of regional branching, measures of relatedness have been less clearly defined. Measures of relatedness often indicate relatedness at various levels—sectoral, industrial, product, or technological-and often indicate a relationship between capabilities belonging to different types of domains (e.g., technology and/or product development, manufacturing processes, marketing, 
management, etc.). For example, one of the most comprehensive attempts to measure relatedness is a measure developed by Neffke and Svensson Henning (2008). It measures co-occurrence of products at the plant level and indicates how manufacturing industries are related in the process of manufacturing. This may, of course, imply some sort of technological commonality between manufacturing industries, but it is not necessarily in line with the above definition of technological relatedness where two industries build on a common or complementary knowledge base in the sense that they rely on shared scientific or engineering principles. The knowledge base involved in innovating or developing a new technology is likely to differ from the knowledge base involved in manufacturing related to the same innovation at a later stage. This is just to illustrate the complexity of defining and measuring relatedness between two or more industries.

It is not the purpose of this article to clarify all the different aspects of the concept of relatedness and the interrelationships among them, but rather to initiate more research on the complexity of technological relatedness. Because technological relatedness is a key component of the regional branching thesis, there is a strong need to disentangle the different dimensions of relatedness and their impact on regional branching.

Because the concept of regional branching is fairly recent, a thorough understanding of the mechanisms through which regional branching operates is lacking. Boschma and Frenken (2011a) tentatively note that firm diversification, entrepreneurial spin-offs, labor mobility, and networking are important mechanisms in the process of regional branching since they all function as channels for knowledge transfer and tend to be locally biased. Although firm diversification and spin-offs represent the start of a new industry, labor mobility and networking can function as knowledge-diffusion mechanisms that trigger firm diversification or spin-offs at a later stage. Firm 
diversification and entrepreneurial spin-offs of emerging industries are thus the key indicators and measures of regional branching, whereas labor mobility, networks, and informal buzz (Bathelt, Malmberg, and Maskell 2004) can secure a high level of knowledge diffusion in a region that may or may not initiate regional branching. In the analysis that follows, the focus is on the nature of direct diversification mechanisms: firm diversification and entrepreneurial spin-offs.

\section{Diversification}

Firms diversify into new technology areas for several reasons. Usually, firm diversification is associated with the processes identified in Penrose's (1959) seminal work on the resource-based view of the firm, where firms tend to diversify into industries that allow them to take advantage of the skills, competences, and routines that they have developed in their activities in related industries. This type of diversification process is said to be characterized by economies of scope based on commonalities in the knowledge inputs into two technological fields (Breschi et al. 2003).

However, firms can also diversify into technologies that are not technologically related to their knowledge bases (e.g., when two knowledge bases do not share the same scientific or engineering principles). For example, when a window manufacturer applies nanotechnology to the production of windows, the company must acquire new competences that involve scientific principles that are not technologically related to the knowledge base of the firm. Similarly, if a car manufacturer diversifies into a type of motive power that is an alternative to the internal combustion engine, it likewise must develop a set of competences that are technologically unrelated to its existing activities. However, it is clear that the window and car manufacturers retain advantages with respect to other types of skills (e.g., product and/or marketing skills). However, in relation to the regional branching thesis, it opens up the possibility that firms diversify into technology areas that are not necessarily cognitively related to their own in the 
sense of sharing common scientific or engineering principles. Consequently, because firm diversification is indicative of regional branching, regions may diversify into new unrelated technology areas when a new technology opens up new technical opportunities and major innovations in user industries.

There are several reasons why technologically unrelated diversification occurs. It may occur because of changes in a firm's competitive environment or because an integration strategy is the best way to facilitate incentive alignment and control innovative activity (Teece 1986). Changes in a firm's environment can be caused by increased competition. For example, when a large part of European textile production was overtaken by newly industrialized countries, some textile firms in Europe moved upstream into areas such as improving and manipulating materials by applying nanotechnology (Fianti, Kaounides, and Stingelin-Stutzmann 2006). Changes in a firm’s environment can also occur because of changes in consumer preferences, heightened regulation, or uncertainty of supply (Arrow 1975).

Spin-offs are another direct source of regional branching. A spin-off is created when employees leave their workplace to establish a new firm based on the skills that they acquired at the parent organization. It is common to distinguish between firm and university spin-offs.

Because firm spin-offs have been shown to resemble their parent company in terms of the spin-off's initial products and markets (Klepper 2001; Klepper and Sleeper 2005), they are likely to be the primary mechanism for regional branching under certain conditions in the case of radical, emerging industries. These conditions could include high levels of research and development in incumbent firms, where such activities result in new ideas that the parent company chooses not to pursue. In the case of large firms, if they decide to cut back on their portfolio activities, entire divisions could be spun off as they become redundant to the firm's strategy. The semiconductor industry is the most 
notable example of an industry with a high rate of firm spin-offs at an early stage of the industry life cycle (Moore 1996; Klepper 2001).

The biotechnology industry is an example of an industry with a high rate of university spin-offs. For example, Zucker et al. (1998) find that the biotechnology industry is driven by embedded tacit knowledge among preeminent scientists who start their own businesses in geographic proximity to their university laboratories.

Accordingly, the spin-off mechanism fulfills the regional branching thesis (see also Boschma and Wenting 2007) regarding technologically related diversification because of two underlying characteristics. First, entrepreneurial spin-offs, whether from firms or universities, have been shown to locate in proximity to their parent organizations (for a review, see Stam 2010). Second, the propensity for spin-offs to enter either the same industry as the parent organization or a new and related industry is much higher than their propensity to enter unrelated industries (Braunerhjelm, Baltzopoulos, and Tikoudis 2012).

\section{Other Knowledge-producing Actors}

The role of other knowledge-producing actors like universities and research institutes in the process of regional diversification should be considered. The literature on regional branching often overemphasizes the role of industrial actors and the linkages between industries, but the literature has paid very little attention to the role of universities and research institutes. To add explanatory power to the concept of regional branching, it is, however, necessary to include other knowledge-producing actors besides the preexisting industry. Particularly in the case of knowledge-intensive industries, university knowledge has been shown to play an important role at the regional level (Zucker et al. 1998; Audretsch 2001). The involvement of universities and research institutes may occur either directly, when they function as breeding 
grounds for entrepreneurial activities (Feldman 2001), or indirectly, when they

reallocate resources to emerging fields (Vargas and Holbrook 2010).

In sum, owing particularly to its temporal and cognitive focus, the regional branching thesis offers an explanation of how new growth paths may be linked to preexisting economic activities at the regional level. However, the regional branching thesis also has several shortcomings (outlined above), which are focused on in the analysis that follows.

\section{Method}

This study focuses on a selection of European regions that represent the majority of fuel cell knowledge production, as approximated by patent applications. The following analytical strategy was employed. First, the European NUTS2 ${ }^{2}$ regions with the largest shares of fuel cell patenting between 1993 and 2007 were identified; second, the largest fuel cell patenting players in each region were identified; and third, the largest players’ development paths into the emerging fuel cell field were examined. This process produced a profile of regions and actors that might not be representative of the emerging industry but that yield qualitative insights into the main regional branching mechanisms for a variety of regions.

The analysis was conducted and constructed using three types of data: patent applications, interviews, and secondary qualitative data.

The main quantitative data source was the Organization for Economic Cooperation and Development (OECD) REGPAT database (OECD REGPAT, December 2010), which covers patent applications filed under the Patent Cooperation

\footnotetext{
${ }^{2}$ European NUTS2 regions are defined as "regions for the application of regional policies" within a threshold of 800,000 to 3 million inhabitants (European Communities 2007). However, there are large differences between NUTS2 regions since some fall outside of the threshold and others do not have any jurisdiction to implement regional policies. Nevertheless, NUTS2 regions are preferred to NUTS1 ("major socio-economic regions" and NUTS3 ("small regions for specific diagnoses") regions for the spatial mapping of new industries.
} 
Treaty, as designated by the European Patent Office. This data set is unique because it is a comprehensive attempt to ascribe a large detailed patent data set to regional statistical units. The mapping of fuel cell patents was based on the address of the inventor because this information was presumed to be a better proxy for the location where knowledge production actually occurs than the address of the applicant. Likewise, the "priority year" was used to date the time of an invention (Ter Wal and Boschma 2009). The International Patent Classification (IPC) system was used to identify the patent applications with fuel cell content. The IPC code "H01M008" refers to the classification of "fuel cells, and manufacture thereof” (WIPO 2014) This method defines fuel cell patent activity rather narrowly, ${ }^{3}$ which is consistent with the purpose of this study, that is, to identify regional players with core development activities.

Once the fuel cell patent applications were identified, the sample was linked to the applicants using the OECD Harmonized Applicants Names (HAN) database, which is a database that attempts to clean and consolidate the many versions of the same applicant name (see Magerman, Van Looy, and Song 2006 for the method). Although the OECD’s standardized harmonization method contributes significantly to cleaning the data, it was still necessary to further clean and consolidate the applicant names manually.

Patents are a much debated data source in innovation studies primarily because patents are not equivalent to innovations, and not all knowledge is patented or patentable. Another disadvantage of patent data is that they are biased toward large companies over small firms because larger firms are better disposed to patent new knowledge, which is a costly endeavor. However, when studying an immature

\footnotetext{
${ }^{3}$ Thus, the sample only included patent applications that have primary fuel cell relevant content. Patents with more secondary relevance to fuel cells were not included in this sample. Examples of the latter include material development that is relevant for many other types of electricity converters, including batteries and hybrid cells, tank devices with possible application options in fuel cell vehicles, or principles for handling different heat sources that are not restricted to specific fuel cell development issues.
} 
technology field, where innovations (such as new products or processes) mainly exist as prototypes, one way to measure progress and activity is to measure the level of knowledge production. ${ }^{4}$ Consequently, for the purpose of this study, patent data yield valuable insights into the shaping of an emerging industry that no other quantitative data set can provide.

Second, interviews were conducted with experts, who are familiar with the fuel cell industry, companies from each node in the fuel cell value chain, and representatives of regional hydrogen and fuel cell organizations. In total, seven interviews were conducted in September and October 2011, three of which were with companies. The companies were selected based on the following criteria: (1) they were located in the identified sample regions (see Table 2); (2) they were the largest fuel cell patenting entities in their respective regions (see Table 3); and (3) each of them had a unique position in the value chain, that is, as an upstream, downstream, or core fuel cell system developer. The firm interviews were based on a semistructured interview guide that addressed (1) the firms' history and experiences since entering the fuel cell area, (2) its state of the art, and (3) its linkages between preexisting economic activities and the emerging activities in fuel cell technology development. The interviewees were subsequently asked to approve the study's interpretation of the firm's activities with regard to fuel cell technology, including the reproduction of quotations.

Finally, various types of documents, such as strategy papers, annual accounts, homepages, newsletters, press releases, and consultancy reports, were used to provide general background data on the sample firms, accounts of the different types of events that have influenced the development of the fuel cell industry, and insights into the state of the industry at different points in time.

\footnotetext{
${ }^{4}$ Note that the quantity rather than the quality of knowledge production was measured.
} 


\section{Analysis}

\section{Identification of Regions Branching into the Emerging Fuel Cell Industry}

Analogous to other studies of the spatial distribution of high-tech patenting (Feldman and Lendel 2010), fuel cell patenting is concentrated in a small group of regions (see Table 1). Of 271 NUTS2 regions, 189 have a share in the 2,165 fuel cell patents applied for between 1993 and 2007. During the same period, 60 percent of total fuel cell patent applications were applied for by 6.6 percent, or 17, of the 271 NUTS2 regions. These numbers confirm a clear pattern of concentration of fuel cell knowledge generation in a small number of regions.

\section{[Insert Table 1 around here]}

However, development during this period reveals a diminishing spatial concentration. The share of fuel cell patent applications recorded by the 17 most active patenting regions decreased from 72 percent in the first period (1993-97) to 52.9 percent in the second period (2003-07). Because this phase is viewed as the fluid phase (Abernathy and Utterback 1978), it reflects increasing entry and decreasing concentration.

Figure 1 illustrates the geographic distribution of the 17 regions that account for 60 percent of fuel cell patenting activity. The map shows a clear concentration of over half of the 17 regions in southern Germany (see Table 2 for a list of regions), in addition to Mecklenburg-Western Pomerania in northern Germany and Cologne in West Germany. Four other countries have NUTS2 regions that are among the most fuel cell knowledgeproducing regions in Europe. These regions include Lombardy in Italy, North Holland in the Netherlands, Ile de France and Rhône-Alpes in France, and the NUTS2 region of Berkshire, Buckinghamshire, and Oxfordshire in southeast England.

[Insert Figure 1 around here] 


\section{[Insert Table 2 around here]}

The geographic distribution confirms, to a degree, the general impression of the geographic distribution of high-tech employment across Europe, supporting the findings of Madsen and Andersen (2010). In 2006, the high-tech sectors accounted for 4.4 percent of total employment in Europe (Meri 2008). In comparison, most of the 17 largest fuel cell patenting regions already had employment shares in the high-tech sectors that were much higher than 4.4 percent in 2000, although an exception was Mecklenburg-Western Pomerania, with an employment share in the high-tech sector of

3.2 percent (see Table 2).

Table 2 also shows the ratio of fuel cell patents per 10,000 high-tech employees, indicating the levels of productivity of the different regions in fuel cell knowledge generation. The relative measure of fuel cell patenting per 10,000 high-tech employees ranges from approximately 1.6 in Ile de France to 28.4 in Middle Franconia. The low number in Ile de France reflects a high level of high-tech employment (415,000 in 2000), equivalent to 8.4 percent of total employment, and reveals that fuel cell knowledge generation accounts for a minimal share of the region's high-tech patents.

The biggest patent-producing regions, as shown in column 5 in Table 2, are the six German regions of Upper and Middle Franconia in Bavaria, Stuttgart and Tubingen in the neighboring federal state of Baden-Wuerttemberg, Cologne in North RhineWestphalia, and Mecklenburg-Western Pomerania in northeast Germany.

It is noteworthy that Mecklenburg-Western Pomerania is among the most productive locations for fuel cell knowledge production since regions in the northeastern part of Germany have been characterized as having relatively inefficient regional innovation systems (Fritsch and Slavtchev 2006). In fact, Fritsch and Slavtchev's assessment of the efficiency of the German regional innovation systems places Stuttgart and the Bavarian regions at the top, while Mecklenburg-Western 
Pomerania is at the bottom of the rankings. The fact that the sample of the largest fuel cell patenting regions comprises regions from each end of the spectrum confirms the window of locational opportunity thesis that new industries can localize in regions independent of current economic centers (Storper and Walker 1989) and consequently can disrupt the existing economic landscape. The next section addresses the mechanisms that have caused the fuel cell industry to develop in these regions and not in others.

\section{Regional Diversification Mechanisms}

Table 3 displays the number of patenting entities, the mean number of patents per patenting entity, the share of university patents, and the largest patenting entity for each of the largest fuel cell patenting regions over a 15 -year period. ${ }^{5}$ The table reveals that the regions vary along three dimensions. First, the number of patenting entities ranges from 8 in Upper Franconia to 47 in Stuttgart and Upper Bavaria. This variation indicates that some regions are dominated by a few players, whereas others exhibit a larger critical mass. The second dimension is the size and type of players. Some regions are dominated by universities and research institutes, whereas others are dominated by either MNEs or small- and medium-sized enterprises (SMEs). Third, as observed in column five in Table 3, there are significant variations in the university shares among the largest fuel cell patenting regions, ranging from 2 percent to 67 percent. It is thus evident that some regions' fuel cell activities are primarily driven by university research. The importance of university research can be observed in Freiburg in Baden- Wuerttemberg (44 percent), Cologne in North Rhine-Westphalia (67 percent), Rhône- Alpes (58 percent), and North Holland (63 percent). In these regions, the largest

\footnotetext{
${ }^{5}$ Large firms can be the dominant applicants in several neighboring regions even if they are located in only one region since the figures are calculated based on where the inventors who have produced the patented knowledge reside. It is, however, assumed that the firm lies in commuting distance of the inventor.
} 
patenting entity (columns 6 and 7) reflects the high university share and represents either a research institute or a university.

\section{[Insert Table 3 around here]}

This finding is noteworthy and confirms that regional branching has many sources. New regional industrial paths are not only constrained to grow from preexisting industrial structures but can emerge from either industrial or academic/engineering research activities. High levels of university knowledge production can serve different functions in supporting increases in new industries in regions owing to the different types of knowledge-transfer channels between universities and industries (Feldman, Feller, Bercovitz and Burton 2002). These channels can include sponsored or collaborative research projects, patents and licensing, educated skilled labor, social networking, and university spin-offs.

The two major knowledge-transferring channels that have characterized the role of universities and research institutes in relation to fuel cell development are collaborative research projects and university spin-offs. Until recently, education in hydrogen and fuel cell technology at the university level has been sporadic (e.g., summer schools, short courses) (Dahoe and Molkov 2007; Macek et al. 2009). Most training has occurred internally in fuel cell companies.

Spin-offs from universities and research institutes constitute another knowledgetransferring mechanism that has a direct impact on regional branching processes. SFC Energy is an example of this phenomenon, although there are many more university spinoffs that the methodological approach used here cannot highlight (see also Upstill and Symington 2002). For instance, in North Holland, the Dutch spin-off company InDEC B.V. was founded in 1999, based on research activities conducted at the Energy Research Centre for the Netherlands (ECN). ECN developed some solid oxide fuel cell (SOFC) components that had market potential. When this potential was recognized, 
production was separated from research activities, and the latter became the basis for InDEC’s activities (Brett et al. 2006).

Table 3 and the above examples illustrate that university knowledge can play an important role in supporting technologically related regional branching processes, particularly in complex, knowledge-intensive emerging industries such as the fuel cell industry. Consequently, universities and research institutes should be included as sources of regional branching.

The remainder of the analysis is dedicated to understanding how the commercial players in Table 3 entered the emerging fuel cell industry. This part is structured based on the players' relationships to the fuel cell value chain (see Table 4 for a description of the fuel cell value chain).

\section{[Insert Table 4 around here]}

\section{Upstream Fuel Cell Component Developers}

Material developers and suppliers of catalysts, electrodes, polymers, membranes, and gas diffusion layers are upstream in the fuel cell value chain (Nygaard 2008). These products and processes are often generic and fit into a wide range of products of which fuel cells constitute a minor part. Node (2) in the value chain encompasses components and sub-ystems such as sensors, membrane electron assembly (MEA), stacks, bipolar plates, fans, hydrogen, and other fuel storage systems. These products are usually generic for the various types of fuel cells and function of various types of applications.

From Table 3, the activities of the Freudenberg Group, BASF, and Johnson Matthey comply with the upper part of the value chain (node $1+2$, see Table 5 ). The Freudenberg Group is located in Karlsruhe in Baden-Wuerttemberg, which is near the automotive industrial agglomeration in Stuttgart. The Freudenberg Group’s large knowledge base and network in the automotive industry encouraged the firm to begin 
research into fuel cell technology, although it did not have clear competences in that field. The Freudenberg Group found that its skills in nonwovens from its textile assets could be used in the development of gas diffusion layers and that its core competences in seal technology could be leveraged to produce seals for fuel cells (Fianti 2009). The Freudenberg Group has thus diversified based on technologically related resources.

\section{[Insert Table 5 around here]}

The large chemical companies of Johnson Matthey and BASF have also diversified based on technologically related resources. Both BASF, located in the border area of Rhineland Palatinate, Baden-Wuerttemberg, and Hessen, and Johnson Matthey, located in southeast England, build on their core skills in catalysts and chemical processes, which they apply to the fuel cell field by developing complete MEAs for proton exchange membrane fuel cells (PEMFC). Johnson Matthey's fuel cell development activities date to the 1950s, when they focused on alkaline fuel cells for the NASA space program and phosphoric acid fuel cells for large stationary power stations. Since 2000, however, Johnson Matthey’s fuel cell activities have been organized in the subsidiary Johnson Matthey Fuel Cells Ltd. in partnership with Anglo Platinum, which owns 17.5 percent of the company, and the company now focuses on MEAs for PEMFC. ${ }^{6}$

BASF has also had experience in another type of fuel cell, namely, the direct methanol fuel cell (DMFC). However, in 2007, BASF changed its technological focus to high-temperature MEAs. BASF's activities today are based on competences and skills that were developed and enhanced in the chemical company Hoechst and spun off as an independent company, Pemeas Fuel Cell Technologies, in 2004. In late 2006, BASF acquired Pemeas, which laid the key building block for BASF's current fuel cell- related activities. Furthermore, BASF builds on its core competences in polymers,

\footnotetext{
${ }^{6}$ http://www.jmfuelcells.com. This site includes financial reports, press releases, etc.
} 
membranes, and catalysts in the development and production of MEAs, and thus builds strongly on technologically related resources. According to the head of BASF's Global Fuel Cell Coordination and Research Centre, Carsten Henschel, BASF has taken an unusual step for chemical companies by moving downstream into developing and producing components. Henschel states,

We are upstream [in the fuel cell value chain, ed.], but if you look at the experiences of chemical companies, this is actually very downstream; usually chemical companies produce monomers or polymers as liquid or powder. In this case, we still have to do more than 30 different production steps to get to the MEA, so it is something like producing a circuit board, something that is very unusual for us. (Henschel telephone interview October 27, 2011)

This quotation emphasizes that technological competences are often developed concurrently with the establishment of new organizational routines.

These three examples highlight the ways in which large chemical companies have diversified on the basis of economies of scope, where competences in their respective knowledge bases are leveraged in the fuel cell technology field. In addition, both BASF and Johnson Matthey have moved downstream and developed the core component of the fuel cell, the MEA, where the electrochemical reaction actually occurs.

These fuel cell component developers illustrate the process of regional branching based on firm diversification. They build on a mix of firm-internal knowledge resources and acquired knowledge, and hence confirm that technologically related regional capabilities embedded in firms can lead to regional branching.

\section{Dedicated Fuel Cell System Developers}

Further downstream in the fuel cell value chain are the fuel cell system developers that integrate subsystems and components into a fuel cell system. This 
segment is represented by three smaller companies: SFC Energy AG, New Enerday, and Nuvera Fuel Cells Europe (see Table 5). These companies are dedicated fuel cell system developers that differ from one another with respect to the type of fuel cells that they develop and their marketing approaches, which often represent the company’s niche.

The three dedicated fuel cell system developers have followed different paths into the fuel cell field. New Enerday, with approximately 10 employees, is a firm spin- off based in Mecklenburg-Western Pomerania. This small firm has the majority of the intellectual property rights in Mecklenburg-Western Pomerania, which has relatively limited patent activity and few patenting entities, perhaps as a consequence of a less efficient innovation system. Founded in 2010, New Enerday is based on fuel cell activities conducted in Webasto's previous subsidiary, Enerday (Boltze telephone interview October 18, 2011). Webasto is a global leading supplier of convertible roofs and heating, cooling, and ventilation systems to the automotive industry. In 2000, Webasto initiated several research projects in fuel cell technology systems, projects that built on its related core competences in heating and auxiliary electrical arrangements. However, in 2010, Webasto sold off its fuel cell development activities, and New Enerday was founded by its current director, Matthias Boltze, who acquired Enerday’s intellectual property rights from Webasto (Boltze telephone interview October 18, 2011).

Another example is SFC Energy AG, located in Bavaria, which is a university spin-off from the Technical University of München. SFC Energy was founded in 2000, based on Dr. Manfred Stefener's application of electrode structures to DMFCs. SFC Energy produces fuel cell systems for leisure markets and off-grid and defense 
organizations. Since 2003, SFC has shipped over 20,000 fuel cell systems to various niche market segments, and it has grown to approximately 100 employees. ${ }^{7}$

Nuvera Fuel Cells Europe was originally the fuel cell subsidiary of the Italian electrochemistry company Group De Nora, and it built its activities on the basis of technologically related competences of the parent company. De Nora Fuel Cells was acquired by the American company, Epyx Corporation, in 2000, which then formed the current Nuvera Fuel Cells. The latter, in addition to its headquarters in the United States, maintains a location in Milan.

In sum, dedicated fuel cell system developers focus on assembling systems and, hence, rely heavily on suppliers of fuel cell stacks and other components and system integrators that integrate systems into products. These firms form a varied group that illustrates the instability of an emerging industry in which firm diversification, spin- offs, acquisitions, and alliances continue to alter the industrial profile.

Nevertheless, these firms also illustrate how regional branching may occur through the mechanisms of spin-offs, building on technologically related localized resources.

\section{System Integrators: Application of Fuel Cell Systems}

Closest to the markets are the system integrators that incorporate fuel cell systems into complete products. Examples include automobiles, combined heat and power systems, laptops, and hearing aids. In the largest European fuel cell patenting regions, Siemens, Daimler, and Renault stand out as system integrators of this type. Although Siemens has primarily focused on developing SOFC systems for application to stationary power units (Pilkington 2003), the carmakers (Daimler and Renault) have sought to develop fuel cell drive systems for vehicle propulsion. All three, however, have diversified into the emerging fuel cell technology because of their relatedness to

\footnotetext{
${ }^{7}$ http://www.sfc.com. This site includes financial reports, press releases, etc.
} 
the markets in which fuel cells are applied and not necessarily because of internal technologically related resources.

The automotive manufacturers' interest in fuel cell technology began with the Canadian firm Ballard Power Systems’ breakthrough at the end of the 1980s, which reduced the cost of a fuel cell system to power a car from approximately US\$50,000 to potentially approximately US\$200 per car (Steinemann 1999). Daimler had been involved in battery technology development, but it determined that fuel cell technology had greater potential owing to the higher energy density level obtainable with high- pressured hydrogen as fuel (Wind telephone interview October 17, 2011). However, moving into the field of fuel cell technology has not been without complications for Daimler because its core competences are technologically centered on the internal combustion engine (ICE) and the skills associated with mechanically moving parts (Wind telephone interview October 10, 2011). In the fuel cell, the core scientific principle is different, and there are no moving mechanical parts in a fuel cell-powered engine. Daimler, therefore, did not possess a high level of in-house capabilities that were technologically related to the core scientific principle of the fuel cell. According to Dr. Jörg Wind of Daimler AG, Daimler first had to build up expertise in fuel cell technology:

First, we had to build up some capacity to understand the technology to decide if it was something that we could do alone or if we would need a partner. . . . The choice was to collaborate with Ballard Power Systems. Twenty to 30 years ago, electrochemical technology and, in particular, fuel cell technology were not among the competences of any car manufacturers. (Wind telephone interview October 10, 2011).

Daimler chose a collaborative strategy for its fuel cell endeavors (Steinemann 1999), thus forming numerous alliances and joint ventures over the past two decades. Today, 
Daimler's activities are organized into two subsidiaries that develop and produce fuel cell stacks and systems, respectively. The fuel cell stack developer and producer is the Automotive Fuel Cell Cooperation, a joint venture with Ford, which owns 30 percent of the company, and Ballard, which owns 19.1 percent of the company and is located in Vancouver, Canada; the fuel cell system integrator and developer is NuCellSys, which is located in Nabern, near Daimler's headquarters in Stuttgart.

The system integrators are thus large MNEs that apply the fuel cell system to various types of products. Exemplified by the case of Daimler, it has been shown that such firms often do not diversify on the basis of internal core competences that are technologically related to the emerging industry. On the contrary, Dr. Jörg Wind (Wind telephone interview October 10, 2011) confirms that Daimler had certain capabilities in electrical drive trains from its prior experience with battery technologies but little particular knowledge of electrochemistry or fuel cells. Consequently, Daimler has had to enhance its in-house competences substantially to work with the technology. In the next section, the implications of the analysis for the conceptualization of regional branching processes are discussed.

\section{Discussion}

The analysis was performed on a profile of regions (17 NUTS2 regions) representing 60 percent of all fuel cell patent applications in Europe during the period 1993-2007. The largest patenting entities in the 17 regions correspond to a segment of the industry that might not be representative of the total population of firms in the emerging fuel cell industry but that, nonetheless, affords qualitative insights into the various types of actors that have initiated regional branching processes in the fuel cell industry. In addition, the sample turned out to have firms that were well distributed along the fuel cell value chain, including several universities and research institutes, 
providing unique insight into the heterogeneity of the actors that currently constitute the fuel cell industry.

The analysis shows that regional branching processes are contextual and are driven by various players, so that regions differ significantly at this early stage. And although it is too early to determine which of the profiled regions, if any, will succeed in creating new industrial paths in the long run, the heterogeneity of regional diversification processes is an interesting finding in itself. It emphasizes the need for qualitative studies of emerging industries in the field of economic geography.

The empirical part depicts an industry dominated by large MNEs that diversify vertically along the fuel cell value chain and by smaller dedicated firms that concentrate on developing and assembling fuel cell systems. The smaller dedicated fuel cell system developers, with the exception of SFC Energy, were part of a firm diversification process before they were spun off or acquired. ${ }^{8}$ Hence, based on the sample of firms, firm diversification appears to be the dominant mechanism through which regional branching operates in the emerging fuel cell industry. ${ }^{9}$ Although it must be noted that the sample may be biased in favor of large companies because of their greater propensity to patent, the need for large players that can make large investments over long periods of time appears to be a characteristic feature of the development of the fuel cell industry. Consequently, such players dominate the regional branching processes.

Most interestingly, the analysis has revealed a gap between the regional branching thesis and the reality that characterizes an emerging industry with regard to the underlying logic of the mechanisms behind regional diversification. Some firm

\footnotetext{
${ }^{8}$ New Enerday is a spin-off founded on the basis of Webasto subsidiary Enerday's activities, and Nuvera Fuel Cells was originally a subsidiary of the Italian De Nora Group.

${ }^{9}$ In a way, the sample of actors represents the surface soil in a soil profile (to maintain the geographic terminology). As such, this study says little about the undergrowth of actors that represent the underlying layer. This group can be characterized by higher levels of spin-offs. Nevertheless, almost 60 percent of all nonuniversity patenting in the sample regions is ascribed to the large players that have been examined in this study.
} 
diversification and spin-off processes build strongly on firm-internal knowledge resources and thus confirm that regional branching is caused by technological relatedness between preexisting activities and the emerging fuel cell industry. However, the analysis has also shown that other types of firms diversify into the emerging fuel cell industry, even though they do not have a high degree of technologically related competences in the new industry. For instance, system integrators have diversified based on their connections to markets in which fuel cells are applied and thus had no technologically related competences relevant to fuel cell technology. Thus, regions may diversify into new unrelated technology areas.

The fact that firms diversify without technologically related competences is an interesting finding since it reveals that regional path-creation processes may be related less to technologically related capabilities than to product or market relatedness, suggesting that the possibilities for regional diversification are much broader than proposed by the regional branching literature. The present study finds that regional branching into new emerging industries may be guided by different logics, depending on regional context. For example, regional branching may be guided by technological relatedness in one region and by product or market relatedness in another. In the latter cases, regional branching processes may be driven by producers that incorporate new technologies into existing product portfolios. This is the phenomenon observed in the present study, but it could also characterize regions where firms apply or integrate emerging generic technologies into their product portfolios or manufacturing processesfor example, when a window or textile manufacturer applies nanotechnology to its manufacturing process, or a firm integrates information technology solutions into its production processes. Consequently, in such cases, it is not the logic of technological relatedness (i.e., building on the same scientific or 
engineering principles) that drives the diversification process, but rather a firm’s association with markets in which new technologies are applied.

However, one might ask why firms choose to diversify into new technology areas in the absence of economies of scope. In the case of the emerging fuel cell industry, technological diversification in the absence of economies of scope may be explained by changes in the external environment and/or by the technology's immaturity (Langlois 1992). For instance, external changes in firms' environments have been induced by the climate debate and the increase in targeted reductions of $\mathrm{CO}_{2}$ emissions. These objectives entail the need for significant changes in the incumbent energy system, changes that large players, such as Daimler and Siemens, cannot disregard. The most notable example is Daimler, where increasing concern about the environmental consequences of ICE cars and the likelihood of increasing environmental regulations has occasioned the need to find a substitute for the ICE in the long run (Van den Hoed 2007). Together with the need to control and align incentives along the value chain (Teece 1986) system integrators have had to expand the boundaries of the firm upstream in the value chain, regardless of the lack of a high degree of technological relatedness (economies of scope).

Finally, what is the long-term outlook for regional branching processes in cases where the underlying logic is not technological relatedness? For example, regional branching of the Stuttgart region into fuel cell technology was triggered by Daimler's diversification into fuel cell technology. Although it is important to note that Daimler's current fuel cell activities are a relatively minor part of its total activities, its diversification process has the potential to stimulate Stuttgart's dense, localized web of suppliers to diversify as well; otherwise, the regional suppliers risk becoming obsolete since they would be unable to adapt to the new technological regime. In particular, as an MNE that operates internationally, Daimler may find it easier (and cheaper) to find 
suppliers elsewhere than to wait for the “old” suppliers to adapt. Thus, a further regional branching process depends on the regional suppliers' capacities to adapt quickly to the structural changes of the existing industry.

In the present situation, large subsuppliers to the automotive industry, such as Bosch, BASF, and Degussa, have begun diversification processes, whereas many small and medium-sized suppliers have adopted a wait-and-see approach (Tanner 2012; Industrie- und Handelskammer Region Stuttgart 2011). However, it is too early to tell whether this development will result in long-term disruption of the Stuttgart automotive cluster or whether the regional automotive component suppliers will step up and search for possibilities in the new technological regime.

Nevertheless, at present, it appears that Daimler has followed the strategy of acquiring knowledge through building strategic alliances or acquiring subsidiaries located in other regions or parts of the world. These findings suggest that the processes of regional branching are complex, sometimes go beyond the logic of technological relatedness, and sometimes involve extraregional knowledge flows.

\section{Conclusion}

This article set out to investigate the mechanisms through which regional branching into the emerging fuel cell industry operate. The study of the emergence of a new industry in "real time” has allowed the concept of regional branching to be refined and added explanatory power to the regional branching thesis. First, the analysis revealed that in the case of the emerging fuel cell industry, regional diversification has primarily been driven by the mechanism of firm diversification. Consequently, the present study complements other studies that have found spin-off activities (Boschma and Wenting 2007; Klepper 2010) to be a driving force behind regional diversification and suggests that the mechanisms by which regional branching are catalyzed vary, 
depending on the industrial and technological context. Nevertheless, there is need for caution with respect to the conclusions that can be drawn, as indirect mechanisms (e.g., networking and labor mobility) through which knowledge is indirectly transferred have been omitted from this study.

Second, in much of the regional branching literature, it has been taken for granted that the process of regional diversification is driven by industrial actors, while the role of universities and research institutes has received limited attention. The present study, by contrast, shows that universities and research institutes clearly play a role in some regional branching processes. The analysis identified four regions where universities and research institutes have played an important role in producing new knowledge relevant to fuel cell technology. This suggests that in knowledge-intensive industries, such as the fuel cell industry, knowledge obtained at universities and research institutes can contribute significantly to some regional branching processes. Consequently, it is proposed that the concept of regional branching more explicitly includes universities and research institutes. In that respect, it would be worthwhile to further explore the role of universities and research institutes in regional branching processes.

Finally, the findings suggest that care should be taken in ascribing the underlying logic of regional branching to the principle of technological relatedness since other principles may also underlie regional diversification processes. This study has shown that one principle that may supplement the principle of technological relatedness is evident when firms diversify by incorporating new technologies into their product portfolios. In such processes, firms do not take advantage of technologically related activities but base their diversification on their relationship to the market in which the new technology is applied. Consequently, these firms’ technical capabilities are of little use since they differ from the knowledge base of the emerging technology. 
Hence, such firms must acquire new knowledge to understand, adapt, and/or develop the new technology. The firms, however, still benefit from skills and routines pertinent to markets, product integration, regulations, etc. Consequently, when firms diversify based on the logic of what might be called application relatedness, a regional branching process is catalyzed that, ceteris paribus, does not build on the principle of technological relatedness.

This finding raises two critical issues for the literature on regional branching, issues that should be the focus of future research on regional branching. First, there may be other underlying logics besides technological relatedness and application relatedness that may catalyze the emergence of new regional industrial paths. It would therefore be highly relevant to explore further the variance of mechanisms and the related underlying logics that cause regional branching into different industries.

Second, another implication of this finding is that it is very important in studies of regional branching to take care in determining what the underlying logic of regional diversification processes is. Additionally, when measuring relatedness (see, e.g., Neffke and Svensson Henning 2008; Boschma et al. 2013), it is even more important to be precise about the type of relatedness. There appears to have been a tendency to ascribe all types of relatedness between economic activities to technological relatedness (e.g., Neffke et al. 2011a; Boschma et al. 2013). Although the present study far from reveals all the consequences of the present findings, the study indicates the value of understanding the differences between different types of relatedness (i.e., technological, application, manufacturing, market, etc.). Accordingly, it would be extremely valuable to investigate and disentangle the relationships between different types of relatedness and how each of them, individually and together, can catalyze regional branching processes. 
Nevertheless, this study has shown how the regional branching thesis contributes to a deeper understanding of industry emergence as a spatial process. Most noteworthy, the strong focus on the dynamic cognitive relationship between preexisting and new economic activities has been extremely valuable in understanding how new industries come into being at the regional level.

In addition to these theoretical achievements, the regional branching thesis opens up new possibilities for policy makers to be more strategic in the design of regional innovation policies, thereby increasing the opportunities for regions to successfully promote emerging industries. However, as the present study has shown, new economic activities may be related to preexisting economic activities in various ways; consequently, the possibilities for a region to diversify into new industry areas may be equally diverse. This insight will hopefully enlighten policy making further, helping policy makers develop and design better policies to stimulate industry emergence based on the regional context.

\section{References}

Abernathy, W. J., and Utterback, J. M. 1978. Patterns of industrial innovation. Technology Review 80:40-47.

Amesse, F., Avadikyan, A., and Legault, L. 2003. Fuel cells in Canada: From entrepreneurship to innovation clustering. In The economic dynamics of fuel cell technologies, ed. A. Avadikyan, P. Cohendet, and J. Héraud, 159-186. Berlin: Springer Verlag.

Arrow, K. J. 1975. Vertical integration and communication. Bell Journal of Economics , 6:173-83. 
Asheim, B. T., Smith, H. L., and Oughton C. 2011. Regional innovation systems: Theory, empirics and policy. Regional Studies 45:875-91.

Audretsch, D. B. 2001. The role of small firms in US biotechnology clusters. Small Business Economics 17:3-15.

Audretsch, D. B., and Feldman, M. P. 1996. Innovative clusters and the industry life cycle. Review of Industrial Organization 11:253-273.

Basu, S., 2007. Recent Trends in Fuel Cell Science and Technology. In S. Basu, ed. Springer.

Bathelt, H., Malmberg, A., and Maskell, P. 2004. Clusters and knowledge: Local buzz, global pipelines and the process of knowledge creation. Progress in Human Geography 28:31-56.

Boschma, R., Minondo, A., and Navarro, M. 2013., . 2013. The emergence of new industries at the regional level in Spain: A proximity approach based on product relatedness. Economic Geography 89:29_ 51.

Boschma, R. A., and Frenken, K. 2006. Why is economic geography not an evolutionary science? Towards an evolutionary economic geography. Journal of Economic Geography, 6:273-302.

. 2011a. Technological relatedness and regional branching. In Dynamic geographies of knowledge creation and innovation, ed. H. Bathelt, M. P. Feldman, and D. F. Kogler, 64-81. London: Routledge, Taylor and Francis. 
. 2011b. Technological relatedness, related variety and economic geography. In The handbook on regional innovation and growth, ed. P. Cooke, B. Asheim, R. Boschma, R. Martin, D. Schwartz, and F. Todtling, 187-197. Cheltenham, UK: Edward Elgar.

Boschma, R. A., and Lambooy, J. G. 1999. Evolutionary economics and economic geography. Journal of Evolutionary Economics, 9:411-29.

Boschma, R. A., and Martin, R. 2007. Constructing an evolutionary economic geography. Journal of Economic Geography 7:537-48.

Boschma, R. A., and Wenting, R. 2007. The spatial evolution of the British automobile industry: Does location matter? Industrial and Corporate Change 16:213-38.

Bourgeois, B., and Mima, S. 2003. Rationales for co-operation between firms and States within an emerging radical innovation. In The economic dynamics of fuel cell technologies, ed. A. Avadikyan, P. Cohendet, and J. Héraud 79-113. Berlin: Springer Verlag.

Braunerhjelm, P., and Feldman, M.P. 2006. Cluster genesis: technology-based industrial development. New York: Oxford University Press.

Braunerhjelm, P., Baltzopoulos, A., and Tikoudis, I. 2012. Spin-off: Individual, firm, industry and regional determinants. Stockholm: KTH Royal Institute of Technology.

Breschi, S., Lissoni, F., and Malerba, F. 2003. Knowledge-relatedness in firm technological diversification. Research Policy 32:69-87. 
Brown, J., Hendry, C., and Harborne, P. 2007. Developing radical technology for sustainable energy markets-The role of new small firms. International Small Business Journal 25:603-29.

Cooke, P. 2010. Regional innovation systems: Development opportunities from the 'green turn.’ Technology Analysis and Strategic Management 22:831-44.

Dahl, M. S., Østergaard, C. R., and Dalum, B. 2010. Emergence of regional clusters: The role of spinoffs in the early growth proces. In The handbook of evolutionary economic geography, ed. R. Boschma and R. Martin205-220. Cheltenham, UK: Edward Elgar.

Dahoe, A., and Molkov, V. 2007. On the development of an International Curriculum on Hydrogen Safety Engineering and its implementation into educational programmes. International Journal of Hydrogen Energy 32:1113-20.

Dibiaggio, L., and Nasiriyar, M. 2009. Rate and dimensions of the technological knowledge base underlying fuel cell innovations. Evidence from patent data. In Innovation, markets and sustainable energy: the challenge of hydrogen and fuel cells, ed. S. Poguts, A. Russo, and P. Migliavacca, 87-101. Cheltenham, UK: Edward Elgar.

Dosi, G. 1988. The nature of the innovative process. Technical change and economic theory. London: Pinter.

European Communities. 2007. Regions in the European Union, Nomenclature of territorial units for statistics NUTS 2006/EU-27. Luxembourg : EUR-OP. 
Feldman, M. P. 2001. The entrepreneurial event revisited: Firm formation in a regional context. Industrial and Corporate Change 10:861-91.

. 2003. The locational dynamics of the US biotech industry: Knowledge externalities and the anchor hypothesis. Industry and Innovation, 10:311-29.

Feldman, M. P., I. Feller, J. Bercovitz, and R. M. Burton. 2002. University Technology Transfer and the System of Innovation. In Institutions and Systems in the Geography of Innovation, ed. by M P Feldman and N Massard. Pp. 55-78 Massachusetts, USA: Kluwer Academic Publishers.Feldman, M. P., and Lendel, I. 2010. Under the lens: The geography of optical science as an emerging industry. Economic Geography 86:147-71.

Fianti, N. 2009. Going against the grain: The de-maturity of the European textile industry. Thesis, Queen Mary, University of London.

Fianti, N., Kaounides, L., and Stingelin-Stutzmann N. 2006. Managing disruptive technology in the textile industry. Materials Technology: Advanced Performance Materials 21:7-14.

Forbes, D. P., and Kirsch, D. A. 2010. The study of emerging industries: Recognizing and responding to some central problems, Journal of Business Venturing 26 589-602.

Freeman, C. 1996. The greening of technology and models of innovation. Technological Forecasting and Social Change 53: 27-39.

Frenken, K., Van Oort, F., and Verburg T. 2007. Related variety, unrelated variety and regional economic growth. Regional Studies 41: 685-97. 
Fritsch, M., and Slavtchev, V. 2006. Measuring the efficiency of regional innovation systems: An empirical assessment: Freiburg, Germany: Technical University Bergakademie Freiberg-Faculty of Economics and Business Administration.

Grabher, G. 2009. Yet another turn? The evolutionary project in economic geography. Economic Geography 85:119-27.

Hellman, H. L., and van den Hoed, R. 2007. Characterising fuel cell technology: Challenges of the commercialisation process. International Journal of Hydrogen Energy 32: 305-15.

Hodson, M. 2008. Old industrial regions, technology, and innovation: Tensions of obduracy and transformation Environment and Planning A 40:1057-75.

Hodson, M., Marvin S., and Hewitson A. 2008. Constructing a typology of H2 in cities and regions. International Journal of Hydrogen Energy 33:1619-29.

Holbrook, J. A., Arthurs, D., and Cassidy, E. 2010. Understanding the Vancouver hydrogen and fuel cells cluster: A case study of public laboratories and private research. European Planning Studies 18:317-28.

Industrie- und Handelskammer Region Stuttgart. 2011. Elektromobilität: Zulieferer für den Strukturwandel gerüstet? Status quo und Handlungsempfehlungen für den Automobilstandort Metropolregion Stuttgart [Electromobility: Are the suppliers ready for the structural change? Status quo and recommendations for the automotive industry in the metropolitan region]. Industrie- und Handelskammer Region Stuttgart April:1-105.

Jacobs, J. 1969. The economy of cities. New York: Random House. 
Klepper, S. 2001. Employee startups in high-tech industries. Industrial and Corporate Change 10:639 -674.

. 2010. The origin and growth of industry clusters: The making of Silicon Valley and Detroit. Journal of Urban Economics 67:15-32.

Klepper, S., and Sleeper, S. 2005. Entry by spinoffs. Management Science 51:12911306.

Langlois, R. N. 1992. Transaction-cost economics in real time. Industrial and Corporate Change 1:99-127.

Macek, J., Bleischwitz, R., Doran, P., and Gnörich, B. 2009. Development of Education and Training Agenda. Roads2HyCom, Deliverable $\quad 8.5$. http://www.roads2hy.com/wp8.html

Madsen, A. N., and Andersen, P. D. 2010. Innovative regions and industrial clusters in hydrogen and fuel cell technology. Energy Policy 38:5372-81.

Magerman, T., Van Looy, B., and Song X. 2006. Data production methods for harmonized patent statistics: Patentee name harmonization. Working paper MSI 0605, Flanders, $\quad$ Belgium: $\quad$ KU https://lirias.kuleuven.be/handle/123456789/228567

Mans, P., Alkemade, F., van der Valk, T., and Hekkert, M. P. 2008. Is cluster policy useful for the energy sector? Assessing self-declared hydrogen clusters in the Netherlands. Energy Policy 36:1375-85. 
Martin, R., and Sunley, P. 2011. Conceptualising cluster evolution: Beyond the life- cycle model? Regional Studies, 45:1299-1318.

Menzel, M. P., and Fornahl, D. 2010. Cluster life cycles—Dimensions and rationales of cluster evolution. Industrial and Corporate Change 19:205-38.

Menzel, M. P., Henn, S., and Fornahl, D. 2010. Emerging clusters: A conceptual overview. In Emerging clusters: Theoretical, empirical and political perspectives on the initial stage of cluster evolution, ed. D. Fornahl, S. Henn, and M. P. Menzel , 1-13. Cheltenham, UK: Edward Elgar.

Meri, T. 2008. Who are the people employed in high-tech and in which regions do they work? Eurostat, Statistics in Focus 51:1-8.

Moore, G. E. 1996. Some personal perspectives on research in the semiconductor industry. In Engines of innovation. US industrial research at the end of an era, ed. R. S. Rosenbloom and W. J. Spencer, 165-172. Boston, MA: Harvard Business School Press.

Musiolik, J., and Markard, J. 2011. Creating and shaping innovation systems: Formal networks in the innovation system for stationary fuel cells in Germany. Energy Policy 39:1909-22.

Neffke, F., and Svensson Henning, M. 2008. Revealed relatedness: Mapping industry space. Papers in Evolutionary Economic Geography No. 08.19. Utrecht, the Netherlands: University of Utrecht. http://econ.geo.uu.nl/peeg/peeg0819b.pdf 
Neffke, F., Henning, M., and Boschma, R. 2011a. How do regions diversify over time? Industry relatedness and the development of new growth paths in regions. Economic Geography 87:237-65.

Neffke, F., Henning, M., Boschma, R., Lundquist K. J., and Olander L. O. 2011b. The dynamics of agglomeration externalities along the life cycle of industries. Regional Studies 45:49-65.

Nelson, R. R., and Winter, S.G. 1982. An evolutionary theory of economic change. Cambridge, MA: Belknap Press of Harvard University Press.

Nooteboom, B. 1999. Innovation, learning and industrial organisation. Cambridge Journal of Economics 23:127-50.

OECD REGPAT, December 2010. Current version can be accessed through: http://www.oecd.org/sti/inno/oecdpatentdatabases.htm

Penrose, E. T. 1959. The theory of the growth of the firm. New York: J. Wiley \& Sons.

Perez, C. 1983. Structural change and assimilation of new technologies in the economic and social systems. Futures 15:357-75.

Pilkington, A. 2003. Technology commercialisation: Patent portfolio alignment and the fuel cell. Portland International Conference on Management of Engineering and Technology PICMET 03.

Pilkington, A., Lee L.L., Chan C. K., and Ramakrishna S. 2009. Defining key inventors: A comparison of fuel cell and nanotechnology industries. Technological Forecasting and Social Change 76:118-27. 
Rifkin, J. 2004. The hydrogen economy. New York: Tarcher/Penguin.

Ruef, A., Markard J. 2010. What happens after a hype? How changing expectations affected innovation activities in the case of stationary fuel cells. Technology Analysis \& Strategic Management 22:317-38.

Stam, E. 2010. Entrepreneurship, evolution and geography. In The handbook of evolutionary economic geography, ed. R. Boschma and R. Martin, 139-161. Cheltenham, UK: Edward Elgar.

Steinemann, P. 1999. R\&D strategies for new automotive technologies: Insight from fuel cells. International Motor Vehicle Program IMVP. MIT, Available online: http://dspace.mit.edu/handle/1721.1/1395

Storper, M., and Walker, R. 1989. The capitalist imperative: Territory, technology, and industrial growth. New York: Wiley-Blackwell.

Tanner, A. N. 2011. The place of new industries: The case of fuel cell technology and its technological relatedness to regional knowledge bases, Papers in Evolutionary Economic Geography No. 11.13. Utrecht, the Netherlands: Utrecht University: http://econ.geo.uu.nl/peeg/peeg1113.pdf .

. 2012. The geography of emerging industry: Regional knowledge dynamics in the emerging fuel cell industry. Kongens Lyngby, Denmark: Technical University of Denmark.

Teece, D. J. 1986. Profiting from technological innovation: Implications for integration, collaboration, licensing and public policy, Research Policy 15:285-305. 
Ter Wal, A. L. J., and Boschma R. A. 2009. Applying social network analysis in economic geography: Framing some key analytic issues. Annals of Regional Science 43:739-56.

Van den Hoed, R. 2007. Sources of radical technological innovation: The emergence of fuel cell technology in the automotive industry, Journal of Cleaner Production $15: 1014-21$.

Vargas, R. A., and Holbrook, J. A. 2010. Globalization of innovation networks: A model of the process. Technology Management for Global Economic Growth PICMET. 2010 Proceedings of PICMET '10: IEEE, Phuket, July 18-22. http://ieeexplore.ieee.org/xpls/icp.jsp?arnumber=5602040

WIPO 2014, World Intellectual Property Organization, International Patent Classification (IPC) Official Publication: http://web2.wipo.int/ipcpub/\#\&version=20140101\&symbol=H01M0008000000

Zucker, L. G., Darby, M. R., and Brewer M. B. 1998. Intellectual human capital and the birth of US biotechnology enterprises. American Economic Review 88:290-306.

Zucker, L. G., Darby, M. R., Furner, J., Liu, R. C., and Ma, H. 2007. Minerva unbound: Knowledge stocks, knowledge flows and new knowledge production. Research Policy 36:850-63. 


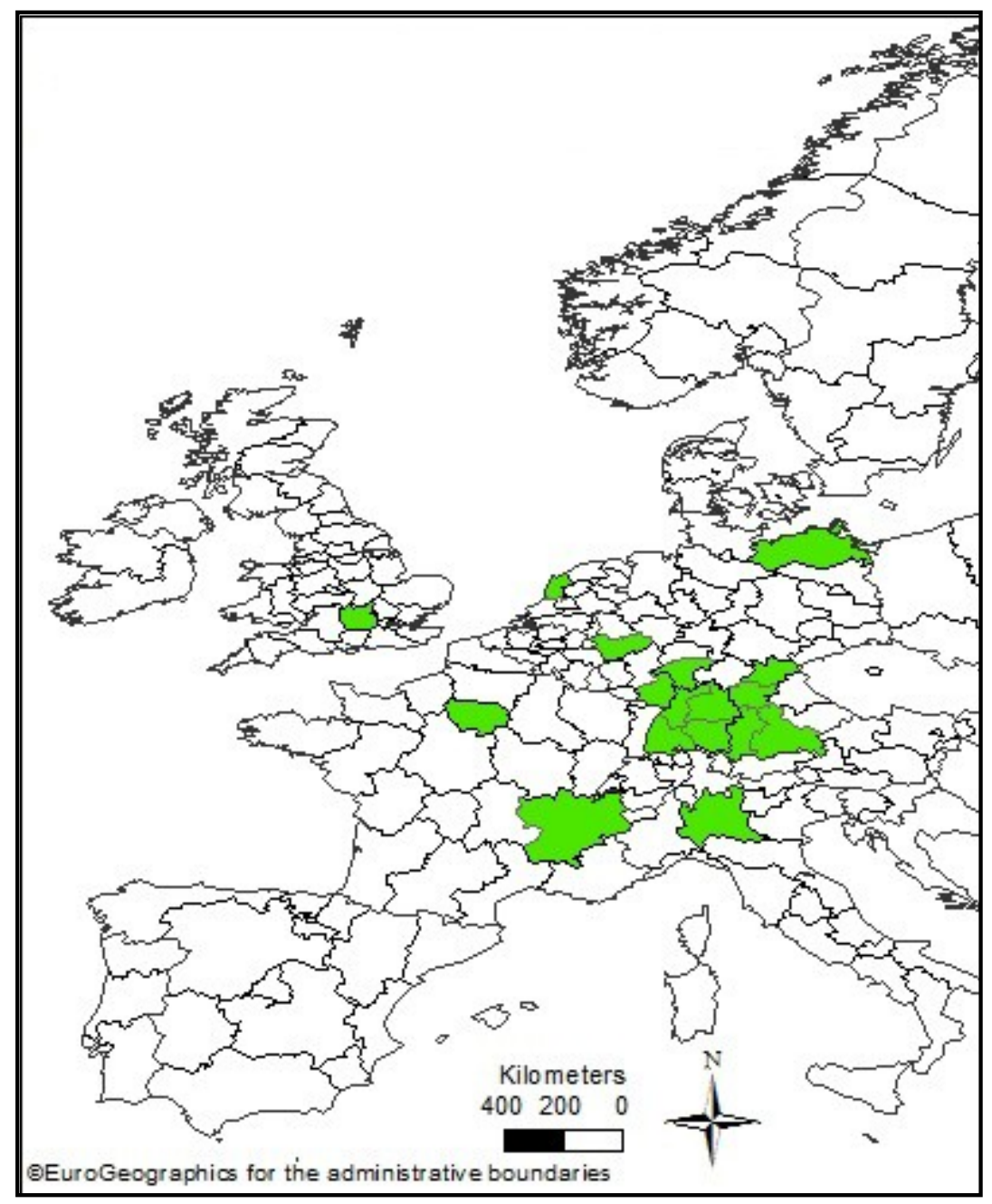

Figure 1.The largest fuel cell patenting regions in Europe, 1993-2007.

Source: OECD REGPAT (OECD REGPAT December 2010). 
Table 1

Distribution of Fuel Cell Patent Applications across the European NUTS2 Regions for Different Periods of Time

\begin{tabular}{|c|c|c|c|c|c|}
\hline \multicolumn{6}{|c|}{ 1993-2007 } \\
\hline $\begin{array}{l}\text { Number of } \\
\text { NUTS2 Regions }\end{array}$ & $\begin{array}{l}\text { Total Fuel } \\
\text { Cell Patent } \\
\text { Count }\end{array}$ & $\begin{array}{l}\text { Percentage of } \\
\text { Total Patent } \\
\text { Count }\end{array}$ & Mean & Median & $\begin{array}{l}\text { Standard } \\
\text { Deviation }\end{array}$ \\
\hline 189 & 2165 & 100 & 11.5 & 3.2 & 25.7 \\
\hline 42 & 1732 & 80 & 41.2 & 20.7 & 42.8 \\
\hline 17 & 1296 & 60 & 76.3 & 68.3 & 49.8 \\
\hline \multicolumn{6}{|c|}{ 1993-1997 } \\
\hline 189 & 209 & 100 & 1.1 & 0.0 & 3.6 \\
\hline 42 & 174 & 83.4 & 4.2 & 1.1 & 6.6 \\
\hline 17 & 150 & 71.9 & 8.9 & 8.7 & 8.5 \\
\hline \multicolumn{6}{|c|}{ 2003-2007 } \\
\hline 189 & 1035 & 100 & 5.5 & 1.5 & 11.5 \\
\hline 42 & 792 & 76.5 & 18.9 & 12.6 & 18.8 \\
\hline 17 & 547 & 52.9 & 32.2 & 28.0 & 23.4 \\
\hline
\end{tabular}

Note: Calculations are based on OECD REGPAT (December 2010). 
Table 2

Regions with Total Patent Applications, European High-Tech Employment, and Fuel Cell Patents per 10,000 High-Tech Employees, 19932007

\begin{tabular}{|c|c|c|c|c|}
\hline NUTS2 Regions & NUTS1 Regions & $\begin{array}{l}\text { Total \# of Fuel Cell } \\
\text { Patent Applications }{ }^{1}\end{array}$ & $\begin{array}{l}\text { High-Tech Share of Total } \\
\text { Employment }^{2}\end{array}$ & $\begin{array}{l}\text { Fuel Cell } \\
\text { Patents per } \\
10,000 \\
\text { High-Tech } \\
\text { employees }^{3}\end{array}$ \\
\hline Stuttgart & Baden-Wuerttemberg & 205.0 & $7.3 \%$ & 15.4 \\
\hline Karlsruhe & Baden-Wuerttemberg & 38.8 & $8.0 \%$ & 4.1 \\
\hline Freiburg & Baden-Wuerttemberg & 42.4 & $7.2 \%$ & 6.2 \\
\hline Tübingen & Baden-Wuerttemberg & 85.1 & $4.8 \%$ & 21.3 \\
\hline Upper Bavaria & Bavaria & 124.3 & $7.5 \%$ & 8.3 \\
\hline Upper Franconia & Bavaria & 35.8 & $4.3 \%$ & 16.6 \\
\hline Middle Franconia & Bavaria & 129.4 & $5.8 \%$ & 28.4 \\
\hline Bavarian Schwabia & Bavaria & 31.2 & $4.2 \%$ & 9.1 \\
\hline Darmstadt & Hesse & 84.3 & $7.3 \%$ & 6.7 \\
\hline Mecklenburg-Western Pomerania & $\begin{array}{l}\text { Mecklenburg-Western } \\
\text { Pomerania }\end{array}$ & 33.6 & $3.2 \%$ & 13.6 \\
\hline Cologne & North Rhine-Westphalia & 152.7 & $5.0 \%$ & 16.9 \\
\hline Rhine-Hesse-Palatinate & Rhineland Palatinate & 42.6 & $5.1 \%$ & 9.4 \\
\hline Ile de France & Île de France & 68.3 & $8.4 \%$ & 1.6 \\
\hline Rhône-Alpes & Center-East & 74.3 & $5.7 \%$ & 5.8 \\
\hline Lombardy & Northwest & 41.9 & $5.0 \%$ & 2.2 \\
\hline North Holland & Netherlands & 38.2 & $5.7 \%$ & 5.3 \\
\hline $\begin{array}{l}\text { Berkshire, Buckinghamshire and } \\
\text { Oxfordshire }\end{array}$ & Southeast England & 68.9 & $12.5 \%$ & 5.0 \\
\hline
\end{tabular}

Source: Calculations are based on OECD REGPAT (December 2010)

(1) regional count is based on inventors' addresses; (2) source: Eurostat (2000); (3) normalized by annual 2000 high-tech employment. 
[W-B: align third column of numbers under heading.]

Table 3

Largest NUTS2 Regions with Number of Fuel Cell Patenting Entities, University Share, and Largest Patentees, 1993-2007

\begin{tabular}{|c|c|c|c|c|c|c|}
\hline \multirow[b]{2}{*}{ NUTS2 Regions } & \multirow[b]{2}{*}{ NUTS1 Regions } & \multirow{2}{*}{$\begin{array}{l}\text { Number of } \\
\text { Fuel Cell } \\
\text { Patenting } \\
\text { Entitites }\end{array}$} & \multirow{2}{*}{$\begin{array}{l}\text { Mean per } \\
\text { Patenting } \\
\text { Entity }\end{array}$} & \multirow{2}{*}{$\begin{array}{l}\text { University } \\
\text { Percent of } \\
\text { Total Patent } \\
\text { Applications }\end{array}$} & \multicolumn{2}{|c|}{ Largest Patenting Entity } \\
\hline & & & & & Percent & Entity Name \\
\hline Stuttgart & Baden-Wuerttemberg & 47 & 4.6 & $14 \%$ & $25 \%$ & DAIMLER \\
\hline Karlsruhe & Baden-Wuerttemberg & 31 & 1.5 & $25 \%$ & $23 \%$ & CARL FREUDENBERG \\
\hline Freiburg & Baden-Wuerttemberg & 17 & 2.5 & $44 \%$ & $41 \%$ & $\begin{array}{l}\text { FRAUNHOFER- } \\
\text { GESELLSCHAFT }\end{array}$ \\
\hline Tübingen & Baden-Wuerttemberg & 39 & 2.1 & $8 \%$ & $39 \%$ & DAIMLER \\
\hline Upper Bavaria & Bavaria & 47 & 2.4 & $6 \%$ & $14 \%$ & SFC ENERGY \\
\hline Upper Franconia & Bavaria & 8 & 5.5 & $2 \%$ & $89 \%$ & SIEMENS \\
\hline Middle Franconia & Bavaria & 19 & 6.7 & $4 \%$ & $83 \%$ & SIEMENS \\
\hline Bavarian Schwabia & Bavaria & 24 & 1.6 & $9 \%$ & $24 \%$ & DAIMLER \\
\hline Darmstadt & Hesse & 38 & 2.2 & $7 \%$ & $15 \%$ & BASF \\
\hline Mecklenburg-Western Pomerania & Mecklenburg-Western Pomerania & 11 & 2.7 & $3 \%$ & $56 \%$ & NEW ENERDAY \\
\hline Cologne & North Rhine-Westphalia & 33 & 4.6 & $67 \%$ & $64 \%$ & $\begin{array}{r}\text { FORSCHUNGSZENTRUM } \\
\text { JULICH }\end{array}$ \\
\hline Rhine-Hesse Palatinate & Rhineland Palatinate & 20 & 2.2 & $6 \%$ & $66 \%$ & BASF \\
\hline Ile de France & Île de France & 29 & 2.8 & $26 \%$ & $37 \%$ & RENAULT SAS \\
\hline Rhône-Alpes & Center-East & 32 & 2.7 & $58 \%$ & $44 \%$ & $\begin{array}{l}\text { COMMISSARIAT A L' } \\
\text { ENERGIE ATOMIQUE }\end{array}$ \\
\hline Lombardy & Northwest & 18 & 2.5 & $1 \%$ & $39 \%$ & NUVERA FUEL CELLS \\
\hline North Holland & Netherlands & 16 & 2.5 & $63 \%$ & $59 \%$ & $\begin{array}{c}\text { ENERGY RESEARCH } \\
\text { CENTER OF THE NL }\end{array}$ \\
\hline $\begin{array}{l}\text { Berkshire, Buckinghamshire and } \\
\text { Oxfordshire }\end{array}$ & Southeast England & 27 & 2.5 & $5 \%$ & $55 \%$ & JOHNSON MATTHEY \\
\hline
\end{tabular}


Table 4

The Fuel Cell Value Chain, Based on Nygaard (2008)

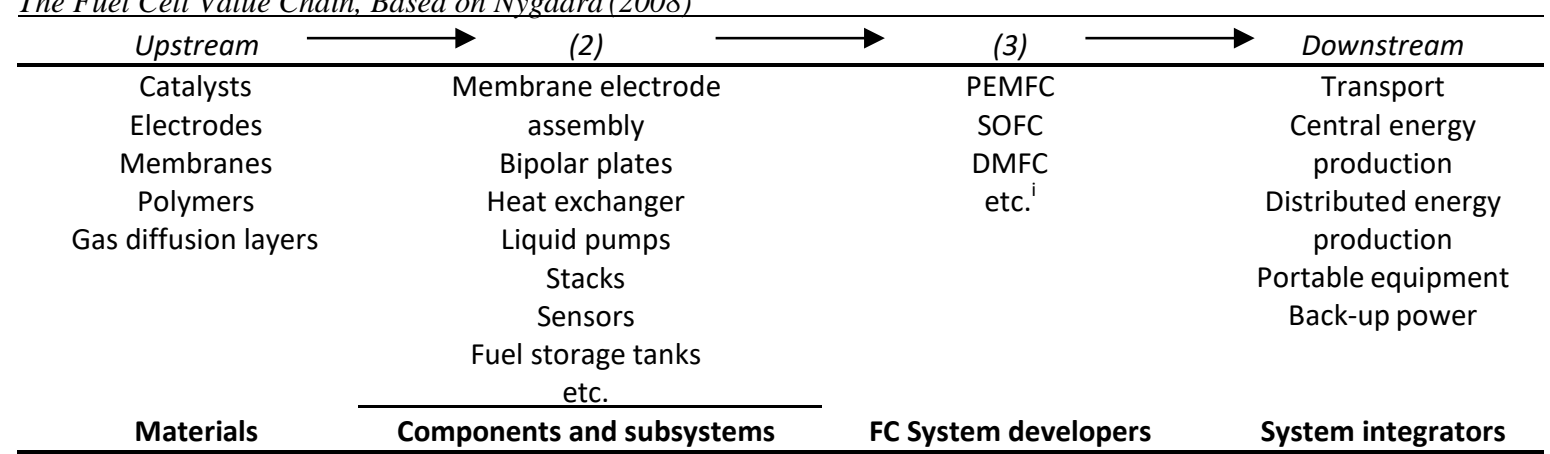

Note: The abbreviations refer to the types of fuel cells, such as proton exchange membrane fuel cell (PEMFC), solid oxide fuel cells (SOFC), and direct methanol fuel cells (DMFC), which are the most common fuel cell systems today. 
Table 5

Firm Diversification Along the Fuel Cell Value Chain

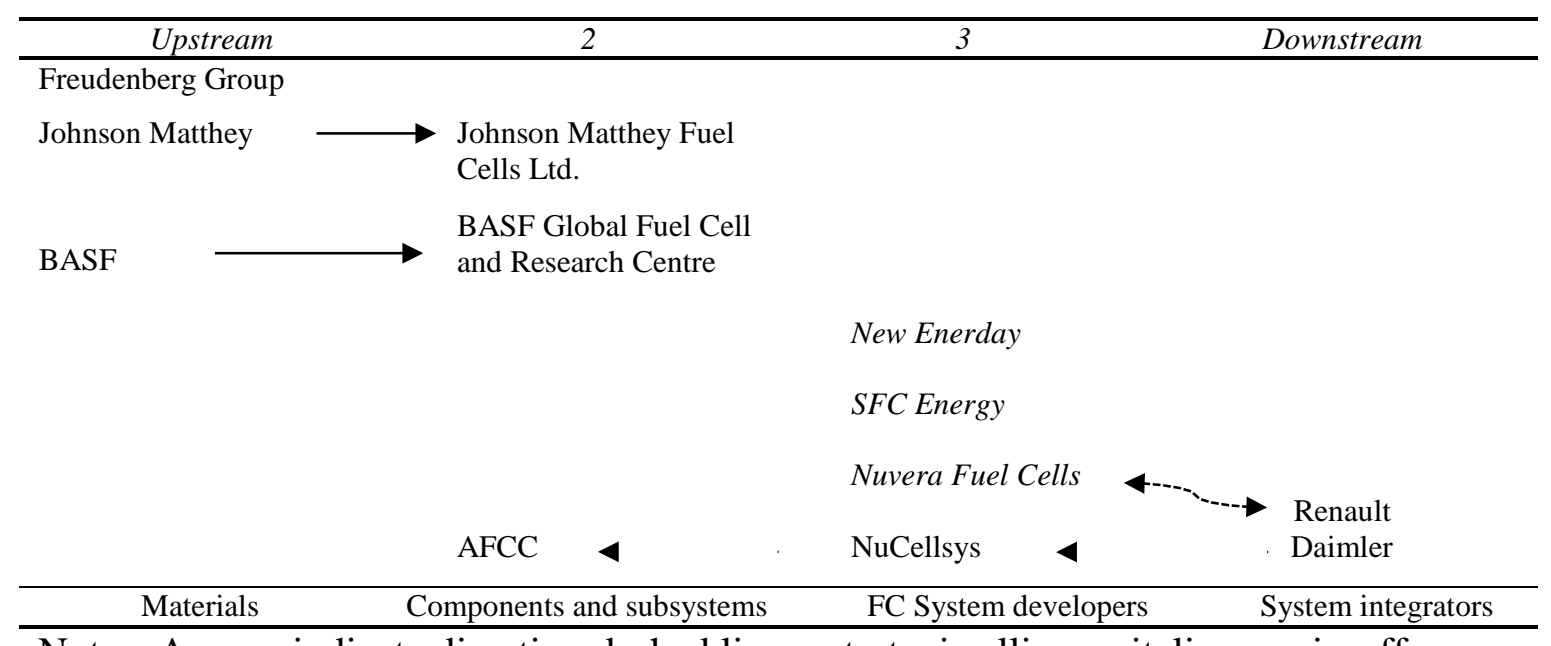

Notes: Arrows indicate direction;dashed line = strategic alliance; italics = spin-offs. 